\title{
Tom Tiddler's Ground: Irregular Medical Practitioners and Male Sexual Problems in New Zealand, $1858-1908$
}

\author{
LINDSAY R. WATSON* \\ 36 Reid Crescent, Allenton, Ashburton, 7700, New Zealand
}

\begin{abstract}
Irregular practitioners ('quacks') specialising in male sexual problems succeeded in nineteenth-century New Zealand by taking advantage of the growing population of unattached men who were ignorant of their own sexual physiology. The irregulars also profited from the regular practitioners' acceptance of ill-defined or imaginary male sexual disorders and the side effects of conventional venereal disease treatments, the lack of a clear demarcation between quacks and the regular medical profession, and an increased availability of newspaper advertising. Improvements in the postal system enabled quacks to reach more potential customers by mail, their preferred sales method. The decline in quackery resulted from scientific advances in the understanding of disease and government legislation to privilege regular practitioners and limit quacks' access to postal services and advertising.
\end{abstract}

Keywords: Sexuality, Quackery, Masturbation, Spermatorrhoea, Electrotherapy

\section{Introduction}

New Zealand has long been a sort of Tom Tiddler's ground for quacks of all descriptions'. ${ }^{1}$

Although there is as yet no detailed history of irregular medical practitioners ('quacks') in New Zealand, it is not a completely neglected field. Researchers have naturally focused on what might be called quackery's golden age: the late nineteenth and early twentieth century - the period in which modern medicine had acquired a persuasive rhetoric but had not yet developed treatments to match. The battle between the factions leading up to the Quackery Prevention Act 1908 has been studied by Louise May; general quackery in the first two decades of the twentieth century has been investigated by Jennifer Gray; and attitudes of

* Email address for correspondence: 1watson@xtra.co.nz

I wish to thank Robert Darby, medical historian, for providing advice and encouragement, and to acknowledge the extensive use made of the National Library of New Zealand's Paperspast website.

${ }^{1}$ The New Zealand Truth, 29 April 1911, 1. 'Tom Tiddler's Ground' refers to an ancient playground game and was the title of a short story by Charles Dickens. Apparently New Zealanders were easy pickings for quacks. 
the medical profession from the perspective of women outlined by Sandra Coney. ${ }^{2}$ While New Zealand quackery during the settlement period has yet to be thoroughly investigated, it is clear that Melbourne and Sydney quacks were the source of much New Zealand activity. The success of male sexual quackery in New Zealand reflected, on a diminished scale, the Australian state of affairs.

A letter-writer to the British Medical Journal (BMJ) in 1883 explained that the vast distances and small population in Australia made preventing quackery difficult and that quackery was 'rampant'. ${ }^{3}$ Quackery in the Australian colonies has been investigated and offers a similar and parallel context for appreciating the New Zealand experience. Some Australian medical histories include the activities of irregular practitioners. ${ }^{4}$ Phillipa Martyr refers to 'a "golden age" of unrestricted medical practice' in Australia, emphasising the range in types of medical practitioners. ${ }^{5}$ A few writers have concentrated on the attitudes to real or imagined male sexual pathologies during this period. David Walker has investigated the concern of nineteenth-century Australia that semen wastage might degrade the physical strength of the workforce. ${ }^{6}$ Robert Darby has discussed the influence of English surgeon William Acton on the approach of Australian doctors Richard Arthur and James Beaney towards masturbation and spermatorrhoea. ${ }^{7}$ Lisa Featherston concluded that, in the late nineteenth century, the Australian medical profession's perception was that the male body could easily slip into sexual excess and deviations. ${ }^{8}$

The present discussion considers the reasons for the successful inroads of quackery into the treatment of male sexual complaints in New Zealand during the second half of the nineteenth century as revealed mainly through newspaper advertising, and therefore excludes consideration of the roles played by itinerant hawkers, traditional M?ori and immigrant Chinese medicine. The advance of sexual quackery in New Zealand was supported by the surplus of adult men in rural districts, the acceptance and open promotion of imaginary male sexual pathologies by some in the orthodox medical community, the considerable range of regulated and unregulated medical practitioners, the rapid growth of the postal system and the advent of daily newspaper advertising from the 1860s.

\section{A Potential Niche Market of Surplus Men}

Much has been made of the influx of men seeking gold, gum and land during New Zealand's colonial period, the resulting sex ratio that favoured males, and the role this

\footnotetext{
${ }^{2}$ Louise May, 'Medical Malversations: Quacks, the Quackery Prevention Act 1908, and the Orthodox Profession's Push for Power' (unpublished BA Hons thesis: University of Otago, 1994); Jennifer M. Gray, 'Potions, Pills and Poisons: Quackery in New Zealand, circa 1900-1915' (unpublished BA Hons thesis: University of Otago, 1980); Camille Guy and Sandra Coney, 'Pink pills for pale people', in Sandra Coney (ed.), Standing in the Sunshine: A History of New Zealand Women since they Won the Vote (Auckland: Viking, 1993), 94-5.

3 J[ohn] W[illiam], 'Springthorpe, 'Medical Registration in Australia', BMJ, 1, 1162 (1883), 689.

${ }^{4}$ Phillippa Martyr, Paradise of Quacks: An Alternative History of Medicine in Australia (Paddington: Macleay Press, 2002); Bryan Gandevia, 'A History of General Practice in Australia' Canadian Family Physician, Australian Supplement, October (1971), 51-61. See also Peter Phillips' popular book Kill or Cure? (Adelaide: Rigby, 1978).

${ }^{5}$ Martyr, ibid., 63.

${ }^{6}$ David Walker, 'Continence for a Nation: Seminal Loss and National Vigour', Labour History, 48 (1985), 1-14.

${ }^{7}$ Robert Darby, 'William Acton's Antipodean Disciples: A Colonial Perspective on his Theories of Male Sexual (Dys)function', Journal of the History of Sexuality, 13, 2 (2004), 171-2.

${ }^{8}$ Lisa Featherstone, 'Pathologising White Male Sexuality in Late Nineteenth Century Australia Through the Medical Prism of Excess and Constraint', Australian Historical Studies, 41, 3 (2010), 337-51.
} 
played in defining Kiwi male culture. In 1861 there were 622 Pakeha [European] females to every thousand Pakeha males, but by 1901 the ratio had stabilised to 900 females to every thousand males. ${ }^{9}$ Offsetting this trend was the large proportion of young males who during the years 1870-1914 did not marry until they were twenty-eight to thirty years of age. ${ }^{10}$ By 1891 two-thirds of adult men lived in rural areas. ${ }^{11}$ This large and scattered population of unattached and mainly impecunious males, the majority of whom were ignorant of their sexual physiology, provided a reservoir of patients for medical practitioners of all types. Suspicious of qualified doctors, whom they regarded as expensive and preoccupied with caring for society's elite, working men were more likely to rely on non-orthodox practitioners and patent medicines supplied through local chemists or druggists. $^{12}$

\section{Diseases of a 'Secret Nature'13}

Before the developments of germ theory and antibiotics, medical practitioners treated real or imagined male sexual diseases of unclear aetiology with a variety of treatments, most of which were ineffective and many of which were dangerous. An aura of sin and shame surrounded symptoms related to the perceived effects of masturbation and spermatorrhoea and venereal disease. The concept that masturbation ('self-pollution') was physically harmful arose in the eighteenth century in the wake of propagandist works such as the anonymous Onania (c. 1716) and Samuel-Auguste Tissot's Onanism (1758) that declared that the loss of seminal fluid could lead to weakening of the intellect, loss of bodily strength, aches and pains, pimples, harmful effects on the genitals and intestinal disorders. ${ }^{14}$ According to degenerative disease and reflex neurosis theories, moreover, excessive stimulation of the nervous system through masturbation could produce serious disease and even death. Public information about the dangers of masturbation was available during the 1860 s through R. and L. Perry's The Silent Friend. ${ }^{15}$ This publication, written by two London surgeons who exhibited quack-like characteristics and who were described as 'pernicious to the welfare of society', was available to New Zealand men via mail order from Sydney. ${ }^{16}$ Any normal male reading their sixty-five page section on masturbation would be convinced that his sexual physiology was quite abnormal.

In the first place the nervous system of the masturbator becomes impaired, the brain, the heart, the lungs become impoverished, and hence arise melancholy, impotence, a bewildered mind, nervousness, and a general decay of the system. 'Tis then that the truth flashes across the mind, and the miserable victim of the folly becomes aware of the extreme wretchedness of his situation, and that he is no longer a fit object for society; a complete imbecile, incapable of sexual intercourse; a man only in form, but not in substance, without the power of exercising his functions either of mind or body: the former participating in

9 Jock Phillips, A Man's Country? The Image of the Pakeha Male, a History (Auckland: Penguin, 1987), 7-8.

10 Ibid., 10.

${ }^{11}$ Phillips, op. cit. (note 9), 10.

${ }^{12}$ Guy and Coney, op. cit. (note 2); Gandevia, op. cit. (note 4). In New Zealand, the terms chemist and druggist interchangeably from the 1840s; the term druggist disappeared by the mid-twentieth century. The term apothecary added veracity to a few newspaper advertisements until the 1870 s.

${ }^{13}$ The North Otago Times, 25 August 1864, 1.

${ }^{14}$ Samuel-Auguste Tissot, Onanism: Or a Treatise on the Diseases Produced by Masturbation (1758) cited in Robert Darby, A Surgical Temptation - The Demonization of the Foreskin and the Rise of Circumcision in Britain (Chicago, IL: University of Chicago Press, 2005), 52.

${ }^{15}$ R. Perry and L. Perry, The Silent Friend (London: R. \& L. Perry \& Co, 1847).

${ }^{16}$ The Daily Southern Cross, 6 April 1858, 4; Edward B. Bowman, Medical Fallacies and Rational Medicine (Sydney: Clarson, Shallard \& Co., 1864), 7. 
the disease, become morbidly affected, and distrust, fear, extreme sensitiveness, and frequently madness ensue. ${ }^{17}$

As the nineteenth century progressed the medical concern over masturbation became more widespread. Concern reached a peak in 1899 when twelve per cent of the men in New Zealand asylums were declared insane due to self-abuse. ${ }^{18}$

The term spermatorrhoea referred to discharge of semen that was not the result of the only rightful Victorian sexual activity, procreative intercourse. Claude Francois Lallemand was the first to document spermatorrhoea in Les Pertes Seminales Involuntairespublished from 1836 to $1842 .{ }^{19}$ Symptomatically spermatorrhoea manifested as spontaneous emissions (including 'nocturnal pollutions') or semen loss during evacuations of the bladder and colon, followed by exhaustion. Dr W.H. Ranking in 1843 outlined a curious range of symptoms including turbid urine, an elongated prepuce, small pendulous testicles and feminisation. ${ }^{20}$ Using papers he had originally published in The Lancet, John Laws Milton produced a book on spermatorrhoea in $1864 .^{21}$ Surgeons generally considered spermatorrhoea a widespread and genuine disease until the $1870 \mathrm{~s}$ and treatments included purgatives, anal leeches, diuretics, laxatives, enemas, suppositories, penile rings coated with chemical irritants and cauterisation. ${ }^{22}$ The infamous Melbourne surgeon and specialist in sexual diseases James George Beaney promoted the concept of spermatorrhoea in Australasia with his book Spermatorrhoea, in its Physiological, Medical, and Legal Aspects, which for New Zealand clients was available from $\mathrm{H}$. Wise of Dunedin in the 1880s. ${ }^{23}$ Self-appointed spermatorrhoea experts advised that one nocturnal emission every ten days or two weeks was harmless, although Philip Muskett of Sydney Hospital allowed up to two per week. Muskett warned that a man suffering from spermatorrhoea should go to an 'accredited and reputable physician'.

If he persists in going elsewhere, instead, he will find that his anxiety of mind will be traded upon, that his condition has not been benefited in the slightest degree, and he has been drained of all the money he possessed. $^{24}$

Darby argues that before circumcision became fashionable in the 1890s there was little the regular practitioners could offer in advance of the quacks to cure masturbation and spermatorrhoea. Removing the foreskin eliminated its stimulatory gliding motion, avoided

\footnotetext{
${ }^{17}$ Perry and Perry, op. cit. (note 15), IX-X.

18 'Reports on Lunatic Asylums of the Colony' and 'Reports on Mental Hospitals of the Dominion', Appendices to the Journals of the House of Representatives of New Zealand, Section H (1880-1920). From 1879 to 1919 the mean incidence of insanity due to masturbation within New Zealand male inmates was approximately five per cent.

${ }^{19}$ Darby, op. cit. (note 14), 181.

${ }^{20}$ W.H. Ranking, 'Observations on Spermatorrhœa; or the Involuntary Discharge of the Seminal Fluid', Provincial Medical Journal and Retrospect of the Medical Sciences, 162 (1843), 93-5.

21 John Laws Milton, On Spermatorrhoea and its Complications (London: Robert Hardwicke, 1864).

22 Ellen Bayuk Rosenman, Unauthorized Pleasures: Accounts of Victorian Erotic Experience (Ithaca, NY: Cornell University Press, 2003), 19, 26.

23 Darby, 'Antipodean Disciples', op. cit. (note 7), 171-2; The Otago Witness, 15 June 1872, 22; James George Beaney also wrote Syphilis, Its Nature and Diffusion Popularly Considered (Melbourne: George Robertson, 1870), which may be a paraphrase of an earlier German work, and The Generative System and its Functions in Health and Disease (Melbourne: F.F. Baillière, 1872). See Phillips, op. cit. (note 4), 114.

24 Phillip E. Muskett, Illustrated Medical Guide, New Zealand Edition (Sydney: William Brooks, 1903), 203, 206. Although in conflict with religion, some physicians prescribed masturbation because they believed disease would result if men did not evacuate semen regularly. See Patrick Singy, 'The History of Masturbation: An Essay Review', Journal of the History of Medicine and Allied Sciences, 59 (2004), 112-21.
} 
the accumulation of irritants and reduced the sensitivity of the remaining organ. The infamous Australasian quacks Howard Freeman and Richard Wallace, who advertised in New Zealand from Sydney and Melbourne late in the century, often used milder remedies and recommended against circumcision, even for phimosis. ${ }^{25}$

The absence of safe and effective treatments, and the embarrassment for men suffering from gonorrhoeal or syphilitic infections, provided other potential prospects for quackery. The Perrys recommended bathing syphilitic chancres in an antiseptic solution of aqueous camphor and copper sulfate. For more serious symptoms they recommended mercurial ointment mixed with 'extract of lead'. ${ }^{26}$ They observed that '[t]housands are annually either mercurialized out of existence, or their constitutions so broken and the functions of nature so impaired, as to render the residue of life miserable'. ${ }^{27}$ Such side effects offered more opportunities for irregular medical entrepreneurship.

\section{'A Dangerous Class of Impostors'28}

Before the dominance of health care by the medical profession in the twentieth century, ailing New Zealand men could choose from a range of irregular providers that included 'herbalists, masseurs, hydrotherapists, osteopaths, electrical therapists or galvanists and hypnotherapists'. ${ }^{29}$ To attempt to classify these medical practitioners either as quacks or regular physicians and surgeons is to assume a false dichotomy - a social construct that results from focusing solely on either end of the practitioner spectrum. ${ }^{30}$ The orthodox medical profession consisted of the practically trained surgeons whose status 'ranged widely from that of high respectability to criminality' and the more academically trained physicians. ${ }^{31}$ Surgeons, rather than physicians, treated venereal diseases. Ellen Bayuk Rosenman says ' $\mathrm{t}$ ]he struggle between quacks and surgeons is a complicated one to analyze with hindsight, since we now realize that, to put it bluntly, surgeons did not know what they were doing either'. ${ }^{32}$ In the 1860s Edward B. Bowman observed that quackery 'pervades the ranks of the profession, and may be recognised by tricks of the outer garment and affectations'. ${ }^{33}$ Registered doctors commonly used poisonous herbal preparations such as aconite (as an antipyretic or analgesic), toxic elements such as arsenic and injected the urethra with caustic substances. ${ }^{34}$ For the purposes of this discussion it is useful to divide nineteenth-century medical practitioners (sens lat) into three classes: (1) registered and trained physicians and surgeons; (2) unregistered (or deregistered) practitioners with at least some medical, pharmacological or herbalist knowledge and training; and (3) the

\footnotetext{
${ }^{25}$ Robert Darby, 'Australia: A New Britannia in Another World', History of Circumcision, available online at http://www.historyofcircumcision.net/index.php?option=com_content\&task=category\&sectionid=6\&id=71\& Itemid $=50$ (accessed 11 March 2012). For a comprehensive account of the use of circumcision to treat masturbation in nineteenth century Britain, see Darby, op. cit. (note 14).

${ }^{26}$ Perry and Perry, op. cit. (note 15), 155-6. Both camphor and copper sulfate have antibacterial properties.

${ }^{27}$ Perry and Perry, op. cit. (note 15), 163-4.

28 'The White Cross League and Quackery', The Lancet, 157, 4042 (1901), 492.

${ }^{29}$ Guy and Coney, op. cit. (note 2).

${ }^{30}$ W.F. Bynum and Roy Porter (eds), Medical Fringe and Medical Orthodoxy, 1750-1850 (London: Routledge, Kegan \& Paul, 1987), 1.

31 Rosenman, op. cit. (note 22), 30.

32 Rosenman, op. cit. (note 22), 33.

33 Bowman, op. cit. (note 16), 18.

34 Quackery Prevention Bill, The New Zealand Parliamentary Debates, 144 (1908), 26; Darby, op. cit. (note 25).
} 
true quacks with no medical, pharmacological or herbalist training. ${ }^{35}$ As happened in Australia, not all immigrant doctors practiced medicine in New Zealand. ${ }^{36}$ For example, Perthshire surgeon Dr James Alexander Robertson Menzies arrived in Southland to take up pastoralism and subsequently entered politics. ${ }^{37}$

The American quack-buster Samuel Hopkins Adams defined a quack as a physician 'who advertises a positive cure for any diseases, who issues nostrum testimonials, who sells his services to a secret remedy, or who diagnoses and treats by mail patients whom he has never seen'. ${ }^{38}$ According to these criteria Dr Beaney could not be classified as a quack, since only his books were advertised alongside their reviews. However, because advertising was associated with quackery, Dr Beaney's penchant for advertising made him very unpopular with his Melbourne colleagues. A Mr Wooldridge stated publicly that '[a]ll the wealth in the world would never induce him to recognise that man. ... [F]or years past Mr Beaney's game had been to advertise himself in every possible way'. ${ }^{39}$ Dr Hugh Johnstone Speer, who was registered to practice medicine in New Zealand, advertised himself as the 'only authorised medical man advertising' ${ }^{40}$ In contrast, the Perrys published their comprehensive book, The Silent Friend, containing testimonials. They also offered secret remedies and cures through their Australasian agents, putting them in the quackery camp.

Ludwig Bruck, an Australian medical journalist, published a List of Unregistered Practitioners in 1886. This lists 15 unregistered New Zealand practitioners, some of whom were obviously mere quack hobbyists or folk healers and none specified that they treated male sexual diseases, although two were electrical therapists. ${ }^{41}$ A perusal of New Zealand newspapers indicates approximately twenty quacks or quack organisations advertising cures for male sexual disorders for extended periods from 1858 until 1908. The majority of these advertisements were for electrical belts.

Few of the lives of these early medical quacks are documented, and some made only fleeting appearances in New Zealand. The Australian-based quacks, in particular, operated from a postal address and advertised in New Zealand papers as well as Australian newspapers sold within New Zealand. New Zealanders then sent money to Australia for advice and treatments. Other quacks moved frequently from place to place to avoid prosecution or over-exploiting each location. The increase in maritime freight and postal steamship services between Australian and New Zealand ports in the 1860s, and the arrival of passenger steamship services in the 1870s, allowed greater numbers of New Zealanders

\footnotetext{
35 Martyr divides Australian medical practitioners into four classes: popular providers (home cures, patient medicines, homeopathy); popular practitioners (masseur, midwife); non-registered practitioners (non-registered includes deregistered); and registered practitioners (allopathic and registered). See Martyr, op. cit. (note 4), 12. 36 Martyr, op. cit. (note 4), 12, 65.

37 John Hall-Jones, 'Menzies, James Alexander Robertson', available online at http://www.teara.govt.nz/en/ biographies/1m42/1 (accessed 14 August 2012).

38 Samuel Hopkins Adams, The Great American Fraud (Chicago, IL: American Medical Association, 1907$), 84$. The American Samuel Hopkins Adams wrote a series of articles for The Collier's Weekly from 1905 exposing medical quackery in the US. His work resulted in the USA Pure Food and Drugs Act 1906. James Mason referred to The Collier's Weekly during the New Zealand Quackery Prevention Bill Hearing in 1907. See 'Report of Quackery Prevention Bill Committee', Appendices to the Journals of the House of Representatives of New Zealand, I-14 (1907), 12.

${ }^{39}$ The Evening Post, 31 March 1879, 2.

${ }^{40}$ The Colonist, 24 February 1888, 3; The New Zealand Gazette, 21 January 1886. Speer was registered 13 October 1885 in Auckland as MD Harvard 1874.

${ }^{41}$ Phillippa Martyr, 'When Doctors Fail: Ludwig Bruck's List of Unregistered Practitioners (1886)', The Electronic Journal of Australian and New Zealand History, 1 November (1997).
} 


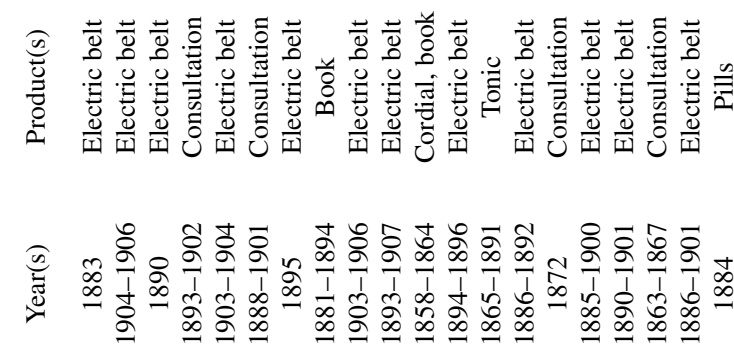

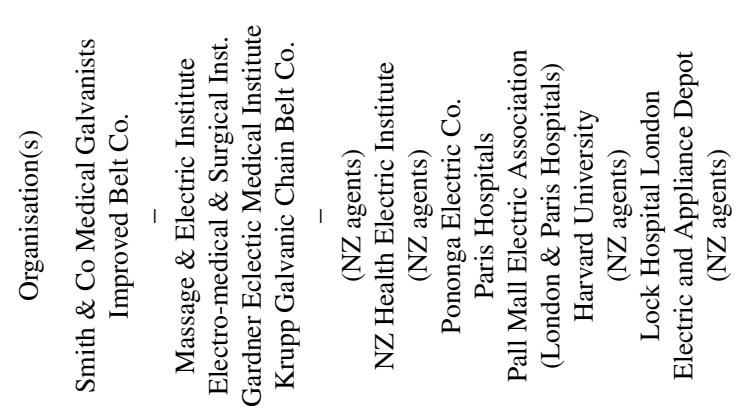

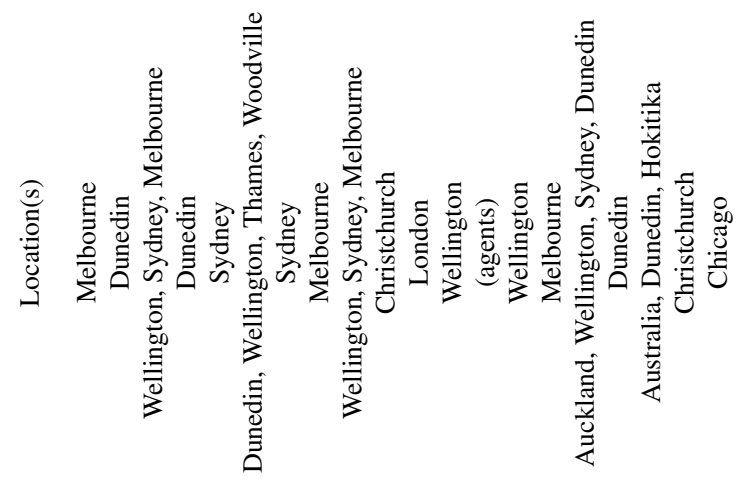

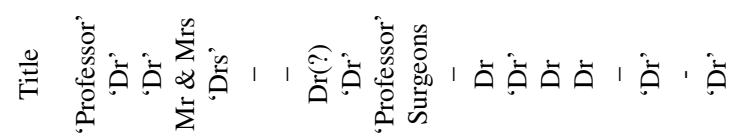


and Australians to travel unimpeded between the two countries as the sealers, whalers and traders had done earlier. ${ }^{42}$ 'Dr' Bell moved between Sydney, Melbourne and New Zealand, and Dr Speer advertised in Auckland, then in Wellington, Sydney, Wellington and Dunedin. Some, like Barron Gardner, travelled within New Zealand. 'Dr' Thomas Marden Trenery emigrated from England to the Victorian goldfields where he practised medicine from 1859. 'Dr' Trenery immigrated to Dunedin in July 1863, to take advantage of the population growth of the Otago gold rush, and set up his dispensary and consulting rooms next door to the Exchange Hotel in Princes Street. Here he hoped to treat 'all Diseases of a Secret Nature, Secondary Symptoms, Eruptions of the Skin, Rheumatism, and all Ailments arising from the indiscreet use of Mercury'. ${ }^{43}$ In August 1864 'Dr' Trenery sold up and moved to Melbourne. ${ }^{44}$ Then, after spending some time in Sydney, he returned to New Zealand, arriving in Hokitika for the West Coast gold rush in $1866 .{ }^{45} \mathrm{He}$ left in 1867 , returned to Australia and set up a 'medical establishment' in Sydney. ${ }^{46}$ 'Dr' Trenery died in 1872 of 'softening of the brain', possibly caused by syphilis. ${ }^{47}$

Some medical quacks appropriated titles, such as 'doctor' or 'professor', or associated themselves with medical institutions to which they had only a tenuous connection. Freeman, of Freeman and Wallace, was not registered as a doctor in Australasia, but assumed the title 'Professor of Electricity'. Wallace 'had served in the British Army and was on the staff of the Homeopathic Hospital, Melbourne'. ${ }^{48}$ Together they operated the Electro-Medical and Surgical Institute in Sydney until 1908 when it closed down following a court case and the Post Office's refusal to deliver the company's mail. Freeman and Wallace published books in which they gave themselves bogus medical credentials, for example Clinical Experiences on Nervous and Private Diseases by the Electro-Medical and Surgical Institute in $1900 .{ }^{49}$ This work was a 'vividly illustrated treatise on sexual complaints' and included chapters on 'youthful follies leading to demoralization, nervous debility, masturbation, spermatorrhoea, impotence, and venereal diseases'. ${ }^{50}$

The Perrys sold The Silent Friend through agents worldwide. 'Drs' McLaughlan and West sold belts and pills respectively through agents and appear to have been unqualified. 'Drs' Austin of Dunedin and Scott of Wellington, and the peripatetic 'Dr' Bell, were all unqualified. It is possible that some quacks had received a modicum of medical experience helping in hospitals or assisting legitimate doctors. 'Dr' Trenery claimed to have been trained in venereal diseases in London's Lock Hospital and appeared in the 1851 London census as a chemist. ${ }^{51}$ Mrs Booth, who ran an enterprise with her husband in Dunedin, claimed to have been trained in London Hospital alongside eminent physicians, including Sir Andrew Clark, Sir Morrell MacKenzie, Sir William Whitney Gull, and Sir William

\footnotetext{
42 David Johnson, New Zealand's Maritime Heritage (Auckland: William Collins, 1987), 104-5.

43 The Otago Daily Times, 13 July 1863, 4; The North Otago Times, 10 March 1864, 5.

44 The Otago Daily Times, 11 August 1864, 3 and 19 August 1864, 4.

45 The Maitland Mercury \& Hunter River General Advertiser (New South Wales), 5 May 1866, 1; The West Coast Times, 9 July 1866, 2.

46 The West Coast Times, 30 October 1867, 3; The Empire (Sydney), 10 April 1871, 1.

${ }^{47}$ Available online at http://home.vicnet.net.au/ adhs/LetterT.html (accessed 9 October 2011).

48 A Melbourne Homeopathic Hospital existed from 1876 to 1934. See http://www.historyofhomeopathy.com. au/hospitals/item/367-the-melbourne-homopathic-hospital.html (accessed 11 November 2011).

${ }^{49}$ Available online at http://www.auspostalhistory.com/articles/1629.shtml (accessed 31 October 2011).

${ }^{50}$ Edward Ford, Bibliography of Australian Medicine 1790-1900 (Sydney: Sydney University Press, 1976).

'Nervous debility' was a term particularly associated with the supposed effects of semen loss.

51 Available online at http://home.vicnet.net.au/ adhs/LetterT.html (accessed 9 October 2011).
} 
Jenner. ${ }^{52}$ Mr Booth had studied 'electro-massage and dry-hot-air, as well as other branches of treatment' in the United States of America (USA) and anatomy in Australia. ${ }^{53}$ Dr Speer claimed a connection to the class of 1874 at Harvard University. ${ }^{54}$

Some represented their own manufacturing businesses: 'Professor' Allen was associated with Smith \& Co., Medical Galvanists of Melbourne, and 'Professor' Notmann with the New Zealand (NZ) Health Electric Institute in Christchurch. ${ }^{55}$ Barron Gardner claimed the qualification MBSA and made much of his 'thirty-five years experience in public practice in England, India and the colonies'. ${ }^{56}$ For a period in 1883, 'Professor' Allen toured the countryside lecturing on the benefits of his electrical belt. ${ }^{57}$ In small isolated and poorly educated communities, medical quacks were able to practice and move on without fear that their qualification claims would be exposed.

\section{Whole Lies out of Half Truths ${ }^{58}$}

In quacks' advertisements we find ...the use of jargon, of classical and oriental names, of royal and cosmopolitan associations, of slick packaging and measures to reassure the wary, and of dramatic presentation. $^{59}$

Jonathan Barry has suggested that the term 'quackery' can be used to describe those 'at the leading edge of advertising' ${ }^{60}$ In the US, Samuel Hopkins Adams warned:

Shut your eyes to the medical columns of the newspapers, and you will save yourself many forebodings and symptoms. Printer's ink, when it spells out a doctor's promise to cure, is one of the subtlest and most dangerous of poisons. ${ }^{61}$

Itinerant quacks needed to establish themselves rapidly when they arrived in a new town. ${ }^{62}$ After arriving in Dunedin from Melbourne in 1864 'Dr' Trenery engaged Edward Perry to distribute his handbills. Unfortunately, Perry was charged with 'dispersing printed papers on which no printer's name was printed' and was fined $£ 5 .{ }^{63}$ Quacks based overseas sent hampers of pamphlets to agents in Wellington for distribution throughout the colony. ${ }^{64}$ While many local newspapers existed before the $1860 \mathrm{~s}$, the first of New Zealand's daily newspapers, The Otago Daily Times, appeared in 1861 using 'industrial age printing technology' that enabled it to supply nearly 3,000 subscribers. ${ }^{65}$ Other dailies

52 Sir Andrew Clark was president of the Royal College of Physicians, knighted and made a baronet. BMJ, 2, 1722 (1893), 1111; Sir William Whitney Gull was Physician-in-Ordinary to Queen Victoria.

${ }^{53}$ Cyclopedia of New Zealand, Otago and Southland Provincial Districts (Christchurch: The Cyclopedia Company, 1905), 254-5. Establishments and individuals paid for their entries in the Cyclopedia.

54 The Wanganui Herald, 12 October 1899, 4.

55 The Oxford Observer, 1 September 1894, 4; The Hawke's Bay Herald, 24 February 1883, 3

56 The Thames Star, 24 August 1900, 3. It is unclear what MBSA means. MB probably indicates 'Bachelor of Medicine'.

57 The Hawke's Bay Herald, 24 February 1883, 3.

58 'Advertising is the art of making whole lies out of half truths'. Attributed to Edgar A. Shoaff.

59 Jonathan Barry, 'Publicity and the Public Good: Presenting Medicine in Eighteenth century Bristol', in Bynum and Porter, op. cit. (note 30), 29-30.

60 Ibid.

61 Adams, op. cit. (note 38), 84.

62 Barry, op. cit. (note 59), 31.

63 The Otago Daily Times, 19 August 1864, 4.

64 'Report of Quackery Prevention Bill Committee', op. cit. (note 38), 15.

65 Patrick Day, The Making of the New Zealand Press: A Study of the Organizational and Political Concerns of New Zealand Newspaper Controllers 1840-1880 (Wellington: Victoria University Press, 1990), 112. 
soon followed, delivered to subscribers via the postal system, with the result that quacks could easily gain access to thousands of men through relentless newspaper advertising. In 1868 the New Zealanders Post Office delivered over one million newspapers, one-fifth of which originated in Australia. ${ }^{66}$ Some quacks advertised in New Zealand newspapers for extended periods using unaltered block advertisements that sometimes overran the paid period as 'dummies'. In one instance a whole column overran for two years. ${ }^{67}$ Newman and Wallace and the McLaughlan Company were exceptional in that they regularly changed their graphics and layouts. Always aware of potential competitors, quacks warned of the ineffectiveness of competing products. The McLaughlan Company proudly declared that 'envious people' had tried to copy their electric belt 'on account of the great Cures made, but all attempts have resulted in utter failure'. ${ }^{68}$ 'Professor' Notmann advised those 'who have wasted time and money sending to post-office addresses in other colonies, should not despair, but should consult, free (...)' ${ }^{69}$ Some quacks used testimonials in their newspaper advertisements and in later private correspondence. While some were probably fakes, it is likely that many testimonials were genuine. Adams explained that the 'ignorant drug taker' after recovering from his disease through the 'natural resistant powers of his body, dips his pen in gratitude and writes his testimonial' in 'the most glowing opinions' while 'the unfavourable lie silent' ${ }^{70}$ A grateful example from the hundreds in Dr Speer's possession declared: '... [I] have been suffering from physical and nervous debility.... and am now gratified to say I am perfectly cured, and a sound, healthy man again' ${ }^{71}$

\section{Awakening Sexual Shame, Guilt and Fear}

Advertising quacks trod a thin line between acceptability and indecency that resulted in a lexicon of code words and phrases evolved to allow public advertising without risking prosecution: diseases of the nervous system, diseases of married life, nervous debility, diseases of a secret nature, ailments arising from the indiscreet use of mercury, secret $\sin$, secret vice, self-abuse, syphilis, secondary affects, gonorrhoea, gleet, stricture, seminal weakness, spermatorrhoea, diseases of men and women, indiscretions of youth, seminal losses, varicocele, over-indulgence and manhood. ${ }^{72}$ 'Dr' Trenery asked in his advertisement:

Are you suffering from the crime of secret sin, the results of which are headache, pains in the groins, nervousness, irritability, shyness, languor, aversion to company, confused ideas, irruptions of the skin, unrefreshed sleep, dislike to your daily avocation, low spirits, loss of appetite, want of manly power and vigour; in fact, a lack of all those attributes that makes man the noblest creature of Creation? ... [S]tricture, the result of malpractice, permanently cured on a new and scientific principle, without pain or medicine. ${ }^{73}$

\footnotetext{
66 'Tenth Report on the Postal Service of New Zealand', Appendices to the Journals of the House of Representatives of New Zealand, E-1, (1869), 11.

67 Ibid. Typesetting was labour intensive, so galleys were changed only when new advertising required it.

68 The Evening Post, 18 January 1905, 2.

69 The Observer, 15 July 1893, 24.

${ }^{70}$ Adams, op. cit. (note 38), 4.

71 The Colonist, 24 February 1888, 3.

72 The Thames Star, 24 August 1900, 3; The North Otago Times, 10 March 1864, 5; The Maitland Mercury \& Hunter River General Advertiser (New South Wales), 5 May 1866, 1; The Wanganui Herald, 12 October, 1899, 4; The Tuapeka Times, 24 May 1890, 6; The Evening Post, 18 January 1905, 2 and 16 November 1883, 4; 'Report of Quackery Prevention Bill Committee', op. cit. (note 38), 11.

73 The West Coast Times, 3 November 1866, 3.
} 
The use of the terms 'crime of secret-sin' and 'malpractice' were designed to instil feelings of guilt and shame likely to be felt by both masturbators and victims of venereal disease. Masturbating males experienced a cycle of sexual release, followed by guilt and fear of ill health or insanity making them easy prey for quacks. ${ }^{74}$ The Australian medical practitioner and politician, Dr Louis Lawrence Smith 'notorious' for his treatment of venereal diseases, advertised widely and responded to his critics arguing that 'advertising showed the worth of his qualifications and thus exposed quacks' ${ }^{75}$ Dr Smith was a specialist in that illdefined condition 'nervous debility' and in the 1870s advertised for New Zealand patients who were suffering from 'despondency, melancholia, loss of spirits, and pluck', and who felt that they were 'wasting and pining, and (...) gradually getting weaker and weaker, from causes they have not courage or desire to acquaint their family attendant with'. Smith advertised for men who have 'been guilty of a secret vice, which has, as it were, eaten into their very vitals'. Many 'old young men', he said, 'consult me, who, though young in years have, through the vice above alluded to, and from their having been quacked by the unqualified and unskillful medical man, at last given up all hope and succumbed'. He saw men 'aged in their very youth, unfitted to fulfill the duties which they were sent on this earth to perform' ${ }^{76}$ The masturbator's fate was to 'lose his manhood', a euphemism for impotence. ${ }^{77}$ He maintained that when a man lost semen he lost 'the essence, as it were of his blood'. ${ }^{78} \operatorname{Dr}($ ?) La Mert's book The Physiology of Marriage, available from Sydney, also described how the powers of manhood were lost or suspended and how they could be re-invigorated and maintained. ${ }^{79}$

Young men concerned about their wet dreams were told that 'Dr' West's Nerve and Brain Treatment, available through agents, was guaranteed for '... involuntary losses and spermatorrhoea caused by over-exertion of the brain, self-abuse or over-indulgence' ${ }^{80} \mathrm{~L}$. Barclay \& Co. in Dunedin sold Dr Ricord's Essence of Life as an '... invaluable remedy [affording] relief, and permanently [curing] all who suffer from wasting and withering of the Nervous and Muscular Tissues, Spermatorrhoea and all Urinary deposits (... )' ${ }^{81}$ Based at the Gardner Eclectic Medical Institute in Dunedin, Barron Gardner was one of the last to promote cures for spermatorrhoea in New Zealand newspapers. He described himself as a specialist in diseases of the genitourinary and nervous systems, and was able to help with 'Nervous Debility, Physical Exhaustion, the Indiscretions of Youth, Seminal Losses, Spermatorrhoea, Skin, Venereal and Allied Disorders' ${ }^{82}$

While the orthodox treatment for syphilis may have resulted in harmful side effects, quacks were unable to offer anything more effective and their potions may have delayed

\footnotetext{
${ }^{74}$ Carolyn Thomas de la Pena, 'The Materials of American Studies: Reading Electric Belts', American Studies, 44, 1-2 (2003), 219-51.

${ }^{75}$ Australian Dictionary of Biography, National Centre of Biography, Australian National University, available online at http://adb.anu.edu.au/biography/smith-louis-lawrence-4610/text7585 (accessed 9 October 2011).

${ }^{76}$ Grey River Argus, 15 February 1872, 4.

77 de la Pena, op. cit. (note 74).

78 Walker, op. cit. (note 6).

${ }^{79}$ The Otago Witness, 7 April 1883, 30.

${ }^{80}$ The Evening Post, 16 November 1883, 4.

${ }^{81}$ The Waikato Times, 24 January 1874, 4.

${ }^{82}$ The Tuapeka Times, 24 May 1890, 6.
} 
potentially effective treatment. Few quacks openly offered to cure venereal diseases. The Perrys offered their Concentrated Detersive Essence to 'purify the system from contamination' due to heavy metals. This was to be used for 'those diseases for which mercury, sarsaparilla, \&c., are not only employed in vain, but too often to the utter ruin of health'. 83 'Dr' Trenery mentions 'secondary symptoms' in his advertisements, suggesting syphilis. ${ }^{84}$ Dr Smith, who had 'devoted the whole of his life to the study and treatment of syphilitic diseases' declared that he was 'the only legally-qualified medical man practicing in these cases', and warned the public against 'applying to other medical men, as a mere glance at the medical register will show them to be impostors, preying upon the lies and pockets of suffering humanity' ${ }^{85}$ A member of the Irving Homeopathic Institute in Sydney wrote confidently that 'I am justified by my experience in saying that my homeopathic treatment will positively affect a complete and lasting cure in all forms of nerve and sexual as well as genitourinary diseases' ${ }^{86}$

Quacks sometimes targeted varicocele, an enlargement of the veins draining the testicles, in their advertisements. Often requiring no treatment, varicocele manifests more commonly in the quack target group of young men aged from fifteen to twenty-five. ${ }^{87}$ McLauchlan's Belt, Freeman and Wallace's Electrical Invigorator Belt and the Krupp Galvanic Belt were all promoted to cure varicocele, as did 'Dr' Langston's electric regenerator. ${ }^{88}$ In postal consultations, when asked to self-examine, young men were horrified to find testicles of different sizes and the wormy texture of the varicocele and were warned they could become impotent without using the appropriate quack remedies. ${ }^{89}$

\section{'Quacked by the Unqualified'90}

Few advertising quacks offered personal consultations. During his Hokitika sojourn, 'Dr' Trenery did offer personal consultations 'confidentially on all complaints of a private nature'. He had private consulting rooms for both sexes and promised to faithfully attend to letters that enclosed $£ 1$. 'Dr' Trenery also published a series of pamphlets on syphilis, gonorrhoea, gleet and stricture, seminal weakness or spermatorrhoea, self-abuse and nervous debility. ${ }^{91}$ In Dunedin, Barron Gardner offered consultations personally, and $\mathrm{Mr}$ and Mrs Booth treated patients with massage and medical galvanism at their Massage Institute or within clients' own homes. Mr Booth worked with men only as a 'Scientific Masseur and Medical Galvanist'. Established in 1891, their institute later branched out into steam and dry hot air cures, but still continued to provide electric baths and galvanic treatments. $^{92}$ By passing a direct current through the patient, galvanic electrotherapy

83 The Daily Southern Cross, 25 January 1864, 6.

84 The North Otago Times, 25 August 1864, 1.

85 The Nelson Examiner and New Zealand Chronicle, 3 July 1872, 2.

86 'Report of Quackery Prevention Bill Committee', op. cit. (note 38), 11.

87 The incidence of varicocele among army reservists in 1917 was $1.1 \%$. 'New Zealand Expeditionary Force, Analysis of the Results of the Medical Examination of Reservists Drawn in the Ballot to 30th June 1917', Appendices to the Journals of the House of Representatives of New Zealand, H-19z, (1917), 3.

88 The Press, 6 July 1905, 5; Otago Witness, 4 November 1903, 14; Hawke's Bay Herald, 12 April 1895, 6; The Press, 20 April 1904, 4.

${ }^{89}$ de la Pena, op. cit. (note 74).

90 Grey River Argus, 15 February 1872, 2.

91 The West Coast Times, 16 July 1866, 4.

92 The Otago Daily Times, 19 May 1894, 3; The New Zealand Tablet, 18 August 1893, 10; The Otago Witness, 3 December 1902, 34; Cyclopedia of New Zealand, op. cit. (note 53). 
aimed to 'heal by stimulating activity in wasted or damaged muscles, and to promote healing by the increase of circulated blood in those areas'. ${ }^{93}$ Clearly the Booths were providing conventional massage and heat therapy that their clients would have valued. However, many orthodox doctors of the day would probably have regarded their galvanic treatments as quackery. ${ }^{94}$ Whether Mr Booth actually treated male sexual complaints is unknown, but the use of a 'static battery' to treat 'nervous disorders' makes it highly probable..$^{95}$

The safer approach was to preserve quack anonymity and distance by hooking clients through postal consultations. The Post Office Act 1858 had laid the foundation for the development of an efficient postal system and the goldfields of Otago, the West Coast and the Coromandel provided an impetus to establish post offices and postal runs in rural districts. ${ }^{96}$ Lightweight mail coaches based on the successful Australian 'Cobb \& Co' design were engaged to reach the outlying post offices. ${ }^{97}$ By $1868,174,912$ letters were leaving New Zealand for Australia and by 1880 the country's 856 post offices were handling almost twenty-four million letters annually. ${ }^{98}$ From Melbourne, Dr Smith promoted consultations by letter at $£ 1$ each to

... those to whom Married Life is a burden. To those who desire to enter into the Marriage Contract. To those who tried their family medical adviser, without the desired relief. And to those who suffer from Spermatorrhoea, and other fearful results of indiscretion in youth. ${ }^{99}$

Nineteenth-century New Zealand newspapers advertised patent medicines (remèdes secrets) manufactured in Australia, Britain, France and the US. ${ }^{100}$ These were not necessarily covered by patents, but were of a consistent form that could be sold by druggists and chemists. According to Brown, in Britain by the mid-nineteenth century 'the marketing of proprietary medicines was largely separated from the orthodox medical practice with a small equivocal area of overlap' and probably the situation in New Zealand was similar. ${ }^{101}$ Although both the regulars and quacks used preparations containing similar components, the medical profession generally disapproved of patent medicines over which they had no control. ${ }^{102}$ Sold by druggists to all classes of society at affordable prices, very few patent medicines were specifically designed for male sexual complaints. ${ }^{103}$ The

93 P.J. Martyr, 'From Quackery to Qualification: Massage and Electrotherapy in Australia, 1870-1914', The Electronic Journal of Australian and New Zealand History 3 March (1997), available online at http://www.jcu. edu.au/aff/history/articles/therapy.htm (accessed 12 September 2012).

${ }^{94}$ In Australia some orthodox practitioners used electrotherapy and others endorsed it. See ibid.

95 The Otago Daily Times, 21 April 1900, 5.

96 Howard Robinson, The History of the Post Office in New Zealand (Wellington: Owen, 1964), 85-126.

97 Ibid., 121.

98 'Tenth Report on the Postal Service of New Zealand', op. cit. (note 66), 10; Robinson, op. cit. (note 96), $128-9$.

99 The Nelson Examiner and New Zealand Chronicle, 3 July 1872, 2. 'Indiscretion' refers to masturbation.

${ }^{100}$ Matthew Ramsey, 'Property rights and the right to health: the regulation of secret remedies in France, 1789-1815', in Bynum and Porter (eds), op. cit. (note 30), 79.

101 P.S. Brown, 'Social context and medical theory in the demarcation of nineteenth-century boundaries', in Bynum and Porter (eds), op. cit. (note 30), 218-19.

102 Ibid. 
Perry's Cordial Balm of Syriacum, advertised in New Zealand papers from 1858 to 1864, claimed to strengthen 'the secretory vessels and the reservoirs at the same time', as well as removing 'radically all the affectations of the genital parts in both sexes; substituting vigour for impotence, and fecundity in place of bareness' ${ }^{104}$ It restored 'the impaired powers of life when exhausted by the follies of youth, maturity, or old age' and was 'a certain cure in all cases of nervous debility produced by early imprudence and various other causes (...)'. 105 Perrys' Cordial may have contained Syrian Oregano (Origanum syriacum L.), a 'blood-purifying' herb. Dr Ricord's Essence of Life could restore 'manhood to the most shattered and debilitated constitution from whatever cause arising, in four weeks'. It permanently cured 'wasting and withering of the Nervous and Muscular Tissues, Spermatorrhoea and all Urinary deposits, which cause incapacity and degeneracy, total and partial prostration, and every other exhaustive derangement of the system'. It would also enable a man to fulfill his 'most sacred obligations'. ${ }^{106} \mathrm{Dr}$ Smith criticised the Perry's Cordial Balm Of Syriacum and Dr Ricord's Essence Of Life as belonging to 'a mass of other quackeries, whose sole province is to extract money out of the pockets of their deluded victims' ${ }^{107}$ Dr Philippe Ricord was a noted Parisian venereologist who may or may not have been directly involved with the patent product carrying his name. It was promoted in New Zealand newspapers during the 1880 s, when he is known to have been financially insecure. ${ }^{108}$ 'Dr' West's Nerve and Brain Treatment was available from the chemist W.C. Fitzgerald in Wellington for five shillings. ${ }^{109}$ The pills came in two boxes; one blue, one red, with detailed instructions to add credibility. 'Take one of the Pills from the box marked No.1, before breakfast and dinner; and on the same day at bed-time take two of the Pills from the box marked No.2. Continue this for the first ten days each month ...' etc. ${ }^{110}$ Indian Herb Powder was recommended for men suffering from sexual debility and promised the '... pleasure of feeling a return of your health, strength, and vitality day by day until you are fully restored to health, strength, and manhood'. ${ }^{111}$ Baxter's Alternative Elixir and Spring Medicine was still being 'highly recommended' for spermatorrhoea in $1892 .{ }^{112}$ Without chemical analyses we cannot be sure of the ingredients used in each of these nostrums. However, similar preparations are known to have contained alcohol, opium or acetanilid. Acetanilid is an aniline derivative that was used from the 1880s as an analgesic and antipyretic, producing unacceptable side effects, including death. ${ }^{113}$ Some preparations contained harmless inorganic compounds or traditional herbs sourced from Nicholas Culpepper's Herbal. ${ }^{114}$

\footnotetext{
103 In Australia patent medicines cost '... anywhere from one shilling and sixpence for a bottle, or a couple of shillings for a box of powders. At the same time, the average fee for a doctor's visit was ten shillings and sixpence, although this could vary greatly (...)'. Martyr, op. cit. (note 4), 100.

104 Perry and Perry, op. cit. (note 15), 113-16, 172.

105 The Daily Southern Cross, 25 January 1864, 6.

106 The Waikato Times, 24 January, 1874, 4; The Kalgoorlie Western Argus (Western Australia), 7 July $1903,1$.

107 The Queanbeyan Age (New South Wales), 27 July 1871, 1.

108 J.D. Oriel, 'Eminent Venereologists. 3. Philippe Ricord', Genitourinary Medicine, 65 (1989), 388-93.

109 The Evening Post, 16 November 1883, 4.

110 Available online at http://www.trocadero.com/surecureantiques/catalog/Antiques:Instruments_and_ Implements100.html (accessed 9 October 2011).

111 'Report of Quackery Prevention Bill Committee', op. cit. (note 38), 11.

112 The Press, 16 December 1892, 7.

113 Adams, op. cit. (note 38), 12-13, 34-38.

114 'Report of Quackery Prevention Bill Committee', op. cit. (note 38), 9.
} 


\section{'This Marvellous Belt' 115}

In February 1883 a 'Professor' Allen, who had been travelling around the North Island, arrived in the small rural town of Waipawa to 'lecture on the almost miraculous properties' of his 'galvanic belt'. ${ }^{116}$

The Professor, who stated he had graduated at Trinity College, Dublin, and who spoke with a twang and accent strongly suggestive of "New Ye-ork City and Ste-yates, by gosh," delivered an extremely learned lecture. One would have hardly thought it possible so much erudition could have been knocked into one man. He talked so of bones and of blood, of nerves and mucous membrane, of brain and stomach, and of the "etseteras" intimately connected with the latter and with the seat of (some people's) thought, that it was really wonderful. Even the very doctors (and I saw both our medicos listening to him) seemed to be struck with wonderment at his comprehensive and marvelous knowledge, and I occasionally heard those doctors gasp, as some novel and exciting bit of "news from the interior" was poured forth. When such an evident impression was made upon the scientists, who stood and drank in the stream of knowledge as though enchanted (I heard afterwards certain reflections dropped which lead me to believe that enchanted is not the word), what could the awe-struck laity do but rush the professor for his magnetic belts? Consequently he did a roaring trade at $5 \mathrm{~s}$ per belt. ${ }^{117}$

'Professor' Allen also sold miniature galvanic batteries to be worn as a necklace to cure nervous debility. ${ }^{118}$ To the public mind of the 1880 s electricity was a technological marvel, and devices such as combs, massage devices, belts and chairs exploited its alleged therapeutic properties, much to the amazement of the orthodox practitioners who were largely excluded from participating in such quackery. From the early 1880s until 1906, twelve or so different brands of galvanic or electric (and magnetic) belts were advertised in New Zealand newspapers. Assuming that the nervous system conducted an ether or fluid form of energy, then electrical energy applied to the body would compensate for the supposed nervous exhaustion resulting from sexual activities. Electrical belts became the desirable and fashionable remedy for nervous debility and 'loss of manhood'. 'It was non-invasive and largely painless in small doses, and, second, it created a prickly sensation of electricity that made it seem as if something were actually being cured' ${ }^{119}$ Belts were typically made of cotton and silk, and contained copper and zinc plates. After being soaked in vinegar and placed around the body while still wet, the zinc and copper plates produced a small current that caused tingling sensations. After several hours the belts dried out and ceased producing any current. ${ }^{120}$ The vinegar fumes and the wearer's perspiration resulted in skin redness and irritation. ${ }^{121}$ With the development of battery packs in the 1890s, dipping in vinegar was no longer necessary and two New Zealand companies are known to have made dry belts. The 'Dr' Austin Improved Electric Belt Co. in Dunedin made 'Dr' Austin's 'non-vinegar' belt. ${ }^{122}$ Established early in 1894, the Pononga Electric Company in Wellington manufactured the Pononga Patent Electric Belt that produced a steady current of up to one amp. 'A gentle current at once passes through the vital organs

\footnotetext{
115 The Cyclopedia of New Zealand, Wellington Provincial District (Wellington: The Cyclopedia Company, 1897), 492-3.

116 Galvanic cells produce direct current. Waipawa, near Hastings in the North Island, had a population of 8,805 in 1891. The New Zealand Official Year Book, 1893.

117 The Hawke's Bay Herald, 24 February 1883, 3.

118 The Daily Telegraph, (Hawkes Bay), 11 September 1886, Supplement, 2.

119 de la Pena, op. cit. (note 74).

${ }^{120}$ The Cyclopedia of New Zealand, Wellington, op. cit. (note 115).

121 The Poverty Bay Herald, 18 August 1906, 4.

122 'Report of Quackery Prevention Bill Committee', op. cit. (note 38), 38.
} 


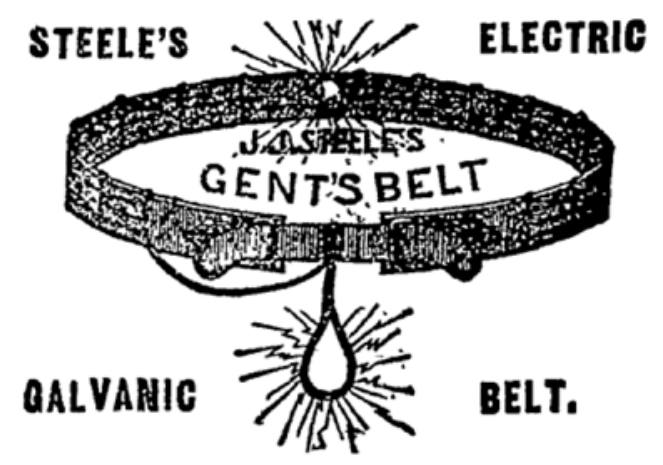

Figure 1: Steele's Electric Galvanic Belt for gents. Source: The Otago Witness, 9 April 1891, 36. National Library of New Zealand.

of the body, whereby organic action is stimulated, the vital energy is renewed, digestion is assisted, and the blood, nerves, and tissues are beneficially influenced'. ${ }^{123}$

Much to the annoyance of the orthodox medical profession, 'Dr' Bell, who lectured in Christchurch and Dunedin, wrote reports of his lecture meetings and had them published as news in The Lyttelton Times and The Press. ${ }^{124}$ 'Dr' Bell's Galvanic Belt had batteries attached to the outside of the belt with thumbscrews at each end and could 'cure' nervous trouble, sexual debility and other disorders. ${ }^{125}$ The 'Favourite' Magneto-Electric Belt dating from 1886 was advertised on the South Island. ${ }^{126}$ It worked by causing the blood to "course more rapidly through veins and arteries. The more quicker runs the vital fluid the clearer and purer its condition - even as the running brook is limpid while stagnant water remains foul'. Different belts were manufactured for each sex. ${ }^{127}$ The Electric 'Invigorator', from the quacks Freeman and Wallace, was worn around the waist for a few hours each night, so it could saturate the nerves with 'new energy', and give 'the strength of youth to the palsied frame.' The belt was recommended for diseases of a 'Nervous and Chronic character' and for '[a]ll classes and conditions of men (...)'. ${ }^{128}$ 'Professor' Notmann, a self-proclaimed electro-medical specialist with twenty years of experience in Europe and three years 'before the New Zealand public', based himself at the NZ Health Electric Institute in Christchurch from 1893 to 1907. Notmann targeted men of all ages who believed they had lost energy through sexual 'error or excesses' (...) 'nervous irritability, exhaustion, loss of energy, and want of development, nervous and wasting debility, weaknesses, etc. (...)'. ${ }^{129}$

Male belts came with a loop, pouch or 'genital sac' in front that was connected by wires to the body of the belt. This surrounded the genitals with a magnetic field from the current flowing from the belt battery. Belts were supposed to be worn for two or three hours per

\footnotetext{
123 The Cyclopedia of New Zealand, Wellington, op. cit. (note 115). The M?ori word pononga may be translated as 'true'.

124 'Report of Quackery Prevention Bill Committee', op. cit. (note 38), 10.

125 The Evening Post, 26 May 1894, 3, available online at http://www.museumofquackery.com/ephemera/drbell. htm (accessed 15 October 2011).

126 The Star, 17 May 1886, 2; Otago Witness, 29 April 1887, 4.

127 The Otago Witness, 29 April 1887, 4.

128 The Observer, 22 March 1902, 23.

${ }^{129}$ The Star, 1 August 1893, 2.
} 
day as they stimulated the genitals by slightly vibrating. ${ }^{130}$ Genital sacs and pouches seem to have been more characteristic of belts produced overseas, such as Steele's, Krupp's and the Electro-Galvanic Suspensory Belts. Steele's Electric Galvanic Belt was available during 1900 and 1901 from Kempthorne, Prosser \& Co. in Dunedin, a company that also sold a ladies' belt. ${ }^{131}$ Steele's advertisement offered a complete cure for lost vitality, lack of manhood, nervous debility, etc. The Krupp Galvanic Belt, sold from Sydney (1890-1) provided 'an unfailing cure for all Nervous, Sexual, or Chronic Diseases'. ${ }^{132}$ Also from Sydney, The German Electric Appliance Agency sold the Electro-Galvanic Suspensory Belt that would 'cure weaknesses in all stages' by producing 'a steady soothing current that can be felt by the wearer through all weak parts'. ${ }^{133}$ The advertisement made it quite clear which part of the body the 'soothing current' was aimed at, since the 'suspensory' was the structure at the front of the belt that encircled the genitals.

\section{Quack Machinations}

Quacks targeted younger men and adolescents because they were easier to manipulate than older men. Some sexual quacks distributed their advertising pamphlets to schoolboys.

A very common practice with such men as Freeman and Wallace, and many others of that type, is to circulate books and pamphlets on sexual ailments in schools. Many boys are guilty of masturbation, and in these pamphlets the results of this habit are pictured in the most awful language. The result is that the boy guilty of the habit becomes for the time being practically unnerved. He is told that the only salvation for him is to send to the publisher of the book, and the boy scrapes up enough money to get some of the medicine. ${ }^{134}$

The Australasian White Cross League was very active in promoting sexual purity in the first three decades of the twentieth century and published pamphlets to warn community leaders of quack trickery. Quacks traded 'upon the ignorance and fears of youth', alluring their victims with 'advertisements of cures for supposed sexual weakness or sexual disorders'. The quacks extorted 'large sums of money either by selling sham, and possibly dangerous, medicines, or by the simpler and more lucrative process of blackmail'. ${ }^{135}$ Medical quacks blackmailed young men by threatening to inform parents of their sexual misdeeds. Dr William Allan Chapple knew of a young man who had failed to raise the $£ 27$.after selling his bike, books and borrowing money to pay for quack medicines that would prevent him ending up in a mental asylum. ${ }^{136}$ Chief New Zealand Health Officer and anti-quackery campaigner Dr James Malcolm Mason recounted the case of a very strict clergyman whose son suffered from 'nervous debility'. The boy stopped sending to the quack for medicine after he had used up all his own money.

Several months afterwards, when he had ceased to send for the medicine, they kept writing him letters, usually marked "Private" and in such a way as to keep them outside the law. The form of the letter was something like this: "We regret to see that you have not been getting your medicine lately." The boy replies that he is getting very much better, although he is practically worse mentally, but he has no money to forward. He reads the books by cable-light in his own room or in outhouses to escape observation. $\mathrm{He}$

\footnotetext{
130 de la Pena, op. cit. (note 74).

131 The Otago Witness, 9 April 1891, 36. Kempthorne, Prosser \& Co. also imported orthodox pharmaceuticals, surgical instruments and medical books. The Waikato Times, 24 January 1874, 4.

132 The Hawke's Bay Herald, 22 June 1895, 5 and 12 April 1895, 6.

133 The Sydney Mail, 9 January 1897, 1.

134 'Report of Quackery Prevention Bill Committee', op. cit. (note 38), 9-10.

135 'The White Cross League', op. cit. (note 28).

136 'Quackery Prevention Bill', op. cit. (note 34), 22.
} 
receives another letter to the effect that they know by observation of such cases that he cannot possibly be cured in the time, and that they feel it to be their duty in the interests of the boy to communicate with his father to see if paternal advice cannot persuade the boy to continue the treatment. The result is that the boy gets a little more money in order to avoid communication with his father, and so the thing goes on. The end of the particular case I refer to was that the boy came to me for something else. He was particularly out of his mind, in a measure, and I said, "Don't you worry. Tell this man that you have seen me", and the boy never heard anything more of the matter. ${ }^{137}$

Another quack strategy was to begin treatment by sending the client a medicine 'calculated to produce precisely the symptoms most likely to alarm him'. A second treatment would then be sent that produced a 'less injurious' effect. As the symptoms of the first treatment disappeared the quack was then able to claim that the treatment was effective and the client believed he had been cured. ${ }^{138}$ Another approach consisted of a series of letters, each hooking the client more firmly into a financial commitment. The first letter offered to cure the complaint completely. The second letter suggested the case was more difficult than initially thought, so more money was requested. The third letter offered a special reduction in price available for two weeks only. The fourth warned to act quickly as the price was further reduced, and so on. ${ }^{139}$ The motto of some quack companies was to 'Keep "em Sick!". 140

\section{Separating the Sheep from the Goats}

[T]he honest attempt to separate the sheep from the goats develops a lamentable lack of qualified candidates for the sheepfold. ${ }^{141}$

Britain passed the Medical Act of 1858 excluding quacks and allowing the legally qualified to practise medicine in any of Her Majesty's Dominions. ${ }^{142}$ This legislation covered nearly all New Zealand's doctors in the nineteenth century, but had little effect on quackery in the colony. Dr Menzies brought a Medical Practitioners Bill before the New Zealand Legislative Council in 1860 to guarantee to the public that all medical practitioners were suitably qualified. It lapsed because Sir Samuel Osborne Gibbes opposed the bill on behalf of Auckland homeopaths. ${ }^{143}$ In 1867 the Postmaster General, John Hall, introduced a bill that became the Medical Practitioners Registration Act of 1869 allowing anyone to be registered if they studied medicine for 'not less than three years duration in a school of medicine or surgery (...) and received a diploma degree or license'. A person 'fraudulently procuring themselves to be registered' could face 'imprisonment with or without hard labour' for up to three years. ${ }^{144}$ An exemption clause allowed eleven men who had practiced medicine before 1867 to register even though unqualified. ${ }^{145}$ By 1901 about seventy-five per cent of New Zealand medical practitioners were registered. ${ }^{146}$

\footnotetext{
137 'Report of Quackery Prevention Bill Committee', op. cit. (note 38), 9-10.

138 'The White Cross League', op. cit. (note 28).

139 Adams, op. cit. (note 38), 109.

140 Adams, op. cit. (note 38), 81.

141 Adams, op. cit. (note 38), 3.

142 M.J.D. Roberts, 'The Politics of Professionalism: MPs, Medical Men, and the 1858 Medical Act', Medical History, 53, 1 (2009), 37-56.

143 Sir Arthur Porritt, 'The History of Medicine in New Zealand', Medical History, 11, 4 (1967), 334-44.

144 'Medical Practitioners Registration Act 1869', The New Zealand Statutes (1869), 169-73.

145 Rex Earl Wright-St Clair, 'Medical Practitioners in New Zealand, 1840 to 1930' (unpublished manuscript, 1989), introduction.

146 Gray, op. cit. (note 2), 47.
} 
In 1872 George Cascoyen declared that Lallemand had been self-deceived and that much harm had been done because spermatorrhoea had been taken up

by the herd of charlatans who fatten upon the vices and fears of men, and it has proved an inexhaustible mine of wealth to the authors of shilling books on "Nervous Debility," to "Silent Friend" (...).

He told of patients consulting doctors and describing their spermatorrhoea symptoms in a 'glib manner' using the 'half technical terms' they had read in quack books. ${ }^{147}$ Cascoyen was categorising spermatorrhoea as quackery and therefore excluding it from the surgeons' domain. ${ }^{148}$ In 1887 the New Zealand Medical Association (NZMA) formed, enabling the profession to exert a more united front against irregular practitioners. Doctors, such as Frederic Truby King, wrote articles in The New Zealand Medical Journal (NZMJ) railing against the advertising of sexual cures. ${ }^{149}$ In 1893 a New Zealand country doctor complained to the NZMJ that a local druggist was advertising 'Why Pay Heavy Doctors' Bills' and charging 30 shillings or more for attendance. ${ }^{150}$ Dr Mason took the lead against the quacks, saying that 'country papers should not be allowed to publish these advertisements, because it is in the country that nine-tenths of these people find their patients (...)'. He justified his statement by saying that country boys were easier to deceive than the town boys. To stop advertisements for quack sexual remedies appearing in schools, he would 'have all the prefects informed that all papers of that kind found in the school should be delivered up, and occasionally a common-sense talk should be given to the boys'. He acknowledged it was a very difficult task and even though he had tried it himself, he had not met with much success. He wondered if working through the District Health Officers to inform the school teachers would help the message filter down to the pupils. 'I think, however, the best results can be obtained through the parents'. ${ }^{151}$ Dr Mason wanted to ban any advertising referring to masturbation because it concentrated

a lad's attention on a portion of his anatomy, while the only cure for this habit is to take his attention away from it. ... [I]n the circulars these men send out they ask questions which in some cases would seem to require a young fellow to masturbate himself in order to answer. ${ }^{152}$

Dr Mason had 'asked the Postmaster to prevent the despatch of these pamphlets throughout the colony.... [T] hey are only sending the book in order to draw in the youngsters' ${ }^{153}$

Purity campaigner Henry Bligh of the Australasian White Cross League travelled throughout the dominion from 1902 lecturing on the 'futility of quack remedies and contrivances for extracting money from dupes who were often persuaded that certain perfectly natural occurrences were the harbingers of bodily breakdown and impotence'. According to Bligh, the Superintendent of Seacliff Lunatic Asylum, Dr Truby King, had said that 'these quacks are sending men here wholesale'. ${ }^{154}$ Bligh was of the opinion that the best way to effectively stop quacks was 'for everyone to refuse to buy such filthy muck'. ${ }^{155}$ In the Wellington Town Hall in June 1906

\footnotetext{
147 George G. Cascoyen, 'Spermatorrhoea and its Treatment', BMJ, 1 (1872), 67-9, 95-6.

148 Rosenman, op. cit. (note 22), 32.

${ }^{149}$ F. Truby King, 'A Plea for Stringent Legislation in the Matter of Corrupt and Immoral Publications', New Zealand Medical Journal, 4 (1890), 18; ibid., 4 (1891), 151-2.

150 The New Zealand Medical Journal, 6 (1893), 65-6.

151 'Report of Quackery Prevention Bill Committee', op. cit. (note 38), 16-17.

152 'Report of Quackery Prevention Bill Committee', op. cit. (note 38), 11-12.

153 'Report of Quackery Prevention Bill Committee', op. cit. (note 38), 15.

154 The Evening Post, 2 July 1906, 5.

155 The New Zealand Truth, 4 July 1908, 5.
} 
Mr Bligh dangled in front of his audience ... an electric belt purchased by an unsuspecting resident of Brisbane for $£ 10 \ldots$. . [A] constant use of the thing was about as effective as a bootlace tied round the waist. ... [I]n his misery the youth wrote to another quack in Melbourne, who relieved him of $£ 16$. Eventually he spoke to Mr Bligh, and was persuaded to call on a doctor. "The result", said Mr Bligh, "was that the doctor charged him $7 \mathrm{~s} 6 \mathrm{~d}$ to tell him he was all right, and the quacks charged him $£ 25$ to tell him he was all wrong! ... [I] have the belt here for inspection", Mr Bligh went on, "anybody who cares to do so can examine it." And he threw it contemptuously on the floor, with the remark: "That is the proper place for it."(Applause.) $)^{156}$

Bligh suggested that postal authorities could refuse 'to deliver letters to these so-called specialists'. ${ }^{157}$ In 1906 the government passed the Post Office Amendment Act prohibiting 'the registering, forwarding or delivering of postal correspondence for treatments of sexual ailments'. ${ }^{158}$ As a result a 'List of Persons, Institutes, and Companies the Registering, Forwarding, or Delivery of Postal Matter for whom is prohibited by the Post Office of New Zealand under Section 9 of The Post Office Amendment Act, 1906' was drawn up. ${ }^{159}$

In 1906 Bligh and Drs Young and Fell from the Wellington branch of the BMA visited the Minister for Justice to urge the prevention of the publication of advertisements by quacks professing to cure sexual disorders. The Minister replied: 'That's a serious thing for the newspapers'. Bligh replied: 'Yes, but a great thing for the lads', adding that

there was no way of protecting young men from quacks unless some such provision was made, and while the law prevented the publication of indecent advertisements there was nothing to prevent the publication of suggestive advertisements.

Apparently Dr Truby King had offered $£ 100$ towards a fund to encourage editors to take such advertisements out of their papers. ${ }^{160}$

Marryat Hornsby introduced a private member's Quackery and Other Frauds Prevention Bill to parliament in $1906 .{ }^{161}$ Hornsby had been an editor of several New Zealand newspapers and was well aware of the workings of quack advertising. ${ }^{162} \mathrm{He}$ told the House that '... if you prevent the circulation of advertisements of this nature - then you do away with nine tenths of the evil'. ${ }^{163}$ Even though there was a concern that so much money was being bled from the country into the pockets of overseas quacks, the bill faced some opposition. ${ }^{164}$ The general public thought that medicine was becoming too 'scientific' rather than 'humane' and that they feared losing access to patent medicines such as 'salts and senna'. There was also the question of M?ori medicine that was reputed to possess 'some of the best herbal remedies for many ailments (...)'. ${ }^{165}$ Yet others wanted to prevent contraception advice or preventatives being promulgated, because '[i]f nature is allowed

\footnotetext{
156 The Evening Post, 26 June 1906, 5.

157 The Evening Post, 13 July 1906, 2.

158 'Report of Quackery Prevention Bill Committee', op. cit. (note 38), 15; The Poverty Bay Herald, 20 March $1907,1$.

159 'Report of Quackery Prevention Bill Committee', op. cit. (note 38), 10.

160 The Evening Post, 13 July 1906, 2.

161 Quackery and other Frauds Prevention Bill, The New Zealand Parliamentary Debates, 136-7, (1906), 406.

162 David Hamer, 'Hornsby, John Thomas Marryat - Biography', Dictionary of New Zealand Biography. Te Ara - the Encyclopedia of New Zealand, available online at http://www.TeAra.govt.nz/en/biographies/3h35/1 (accessed 6 November 2011).

163 Quackery Prevention Bill, op. cit. (note 34), 16.

164 Gray, op. cit. (note 2), 28; Quackery and Other Frauds Prevention Bill, op. cit. (note 161), 412, 426; Quackery Prevention Bill, op. cit. (note 34), 20.

165 Quackery and Other Frauds Prevention Bill, op. cit. (note 161), 434.
} 
to take its course, the nation will increase and the people will flourish' ${ }^{166}$ The public saw the campaign against quackery as '... part of a wider effort on the part of doctors to establish their own professional standing and assert a monopoly over the management of bodily (and some mental) functions'. ${ }^{167}$ Some did not want to lose access to 'able metaphysicians' who used 'mental healing or suggestive therapies' such as hypnotism. Such concerns resulted in a petition to Parliament asking for 'reputable herbalists' to be exempt. ${ }^{168}$

The editor of the NZMJ observed that opponents of the bill said they 'have found these advertised remedies very useful, far better than doctor's prescriptions, and you want to prevent us getting them in order to heap up riches for a close profession'. ${ }^{169}$ Some politicians were afraid that it would place 'a monopoly in the hands of the medical profession'. ${ }^{170}$ Dr Chapple assured the House that it was of 'no personal advantage to the medical profession to suppress quackery'. ${ }^{171}$ The Quackery Committee report recommended the prevention of

the advertising and supply of any preparation, medicine, or appliance alleged to be for the prevention, alleviation, or cure of any human ailment or physical defect, that ... is harmful to health or fraudulent in nature, or cannot effect the purpose for which it was supplied,

to make it unlawful 'for any person to sell, offer or attempt to sell or supply' such medicines or appliances, 'to make it unlawful for any person (...) to unwarrantably use the name of any medical man or false title, such as "Dr —-'s Patent Cure", and 'to make it unlawful for any person other than a duly registered medical practitioner (...) to sell or supply any appliance or preparations which may be used for preventative purposes'. ${ }^{172}$

After two years of debate and various drafts, the Quackery Prevention Act became law in January 1909. This prevented the advertising of any

medicine, preparation or appliance for the prevention, alleviation, or cure of any human ailment or physical defect, and which is false in any material particular relating to the ingredients, composition, structure, nature, or operations of the article (...).

This applied to newspaper advertisements and advertisements sent through the post. The fine for the first conviction was $£ 100$ and the advertiser or the publisher could be liable. ${ }^{173}$

\section{'The Sexual Quack has been Abolished'174}

Before the first decade of the twentieth century had drawn to a close, several battles had been won in the war against sexual quackery in New Zealand. On 21 August 1901 Barron Gardner 'was fined $£ 30$ and costs for fraudulently practising as a medical man'. ${ }^{175}$ As a result of the Post Office Amendment Act 1906, the list of organisations and persons prohibited from receiving mail from the Post Office included the Australians Freeman

\footnotetext{
166 Helen Smyth, Rocking the Cradle; Contraception, Sex and Politics in New Zealand (Wellington: Steele Roberts, 2000), 13-14; Quackery and Other Frauds Prevention Bill, op. cit. (note 161), 413.

167 Darby, Australia - A New Britannia, op. cit. (note 25).

168 The Nelson Evening Mail, 10 September 1906, 1; Quackery Prevention Bill, op. cit. (note 34), 24.

${ }^{169}$ Editorial, The New Zealand Medical Journal, 5 (1906), 32-3.

170 Quackery Prevention Bill, op. cit. (note 34), 20.

171 Quackery Prevention Bill, op. cit. (note 34), 21.

172 'Report of Quackery Prevention Bill Committee', op. cit. (note 38), Introduction.

173 The New Zealand Gazette, 247 (1908), 177-8.

174 The Feilding Star, 9 October 1908, 2.

175 The Thames Star, 22 August 1901, 4.
} 
and Wallace and their several companies, the Irving Homeopathic Institute in Sydney and 'Dr' Bell. New Zealand companies and individuals on the banned list included 'Dr' Austin of the Improved Belt Company in Dunedin, Herr Rassmussen of Wellington, 'Dr' Jilmslie of Christchurch, 'Professor' Notmann of Christchurch and A.J. Tarrant of Christchurch. ${ }^{176}$ In 1907 the London representative of the 'Dr' McLaughlan Electric Belts Company was prosecuted for 'illegally holding himself out as a qualified medical practitioner'. ${ }^{177}$ In Sydney in 1908 legal action against the Freeman and Wallace Medical Institute for improper treatment resulted in $£ 450$ damages being awarded to the plaintiff. In November Howard Freeman was sent to jail for 'prevarication and evasion in connection with his bankruptcy'. ${ }^{178}$ Henry Bligh claimed that he was responsible for closing down the Wellington Branch of the McLaughlin Electric Belt Co. and rejoiced that 'today there is no such thing as the sexual quack in New Zealand. He has been abolished' ${ }^{179}$

Excluding quacks from newspaper advertising and postal communication introduced a very effective barrier between irregular practitioners and their clients, and allowed the regulars to commandeer the 'male sexual problems' territory. Spermatorrhoea disappeared from the orthodox disease list around 1890 and from 1910 Salvarsan replaced the mercury compounds as the preferred treatment for syphilis. ${ }^{180}$ Nonetheless, the New Zealand medical profession continued to accept the Victorian belief that masturbation caused insanity until the 1920s, and as late as the 1940s prevention of masturbation persisted as one of several orthodox medical justifications for the then widespread practice of routine infant circumcision. ${ }^{181}$

176 'Report of Quackery Prevention Bill Committee', op. cit. (note 38), 10; The Poverty Bay Herald, 20 March 1907, 1; The Feilding Star, 22 July 1907, 2; The Poverty Bay Herald, 29 July 1907, 2.

177 'Report of Quackery Prevention Bill Committee', op. cit. (note 38), 11.

178 The Wanganui Herald, 21 November 1908, 5.

179 The Tuapeka Times, 30 October 1907, 3; The Feilding Star, 9 October 1908, 2.

${ }^{180}$ One case of spermatorrhoea was recorded in NZ Military Camps during 1918. 'New Zealand Expeditionary Force', Appendices to the Journals of the House of Representatives of New Zealand, 1919, I, H-19b, 41.

181 'Reports on Lunatic Asylums of the Colony', op. cit. (note 18); F. Truby King, Feeding and Care of Baby. (London: Macmillan, 1913), 122-3; A.D. Latham, 'Masturbation and Mental Illness', The New Zealand Medical Journal, 36, 195 (1937), 319-21; F. Truby. King, Feeding and Care of Baby (Christchurch: Whitcombe \& Tombs, 1942), 218-20. 